\title{
BARONG USING Optimalisasi Seni Pertunjukan sebagai Obyek Pariwisata Budaya Using
}

\author{
Muhammad Agung Pramono Putro, Bambang Soepeno, \\ Rully Putri Nirmala P \\ muhputro@gmail.com \\ Universitas Jember
}

\begin{abstract}
Barong Using is a performance art which is native to the Using community. Barong Using is used as a sacred necessity for clean village rituals. Rituals are held twice a year. The Ider Earth Ritual on the 2 nd of Shawwal and the moon village salvation ritual were recited. The cultural development of bringing the art of barong performance functions as a sacred and profane need. There are efforts to optimize the art of barong performance by the use of tourism. The problems contained in this study are related to discussing (1) the history of Barong Kemiren's performance in which it examines ritual processions with socio-cultural values; and (2) efforts to optimize the art of barong performance later using communities in 1996-2018 as the use of tourism. The research method used is the historical research method by using a cultural anthropology approach to study cultural change and using structural functionalism theory to analyze the shift in barong function socially as a result of tourism. The results of this discussion, the optimization of the art of barong performance is packaged in the interrelationships of the five pillars that support the development of tourism and creative industries, namely, the state, art and ritual actors, supporting communities, industry, and religious leaders. These pillars can provide the right input so that a good response emerges from entrepreneurs, bureaucrats, cultural practitioners, and practitioners of traditional and ritual arts. Now the art of barong performance has undergone many changes starting from the structure of performances and interludes which accompany.
\end{abstract}

Key words: Performing arts, Barong, Tradition, Using, Tourism.

\section{Pendahuluan}

Perkembangan jaman membuat apresiasi masyarakat terhadap seni tradisional mengalami penurunan, tetapi saat ini terdapat salah satu jenis seni pertunjukan tradisional yang berusaha mempertahankan eksistensinya. Jenis seni pertunjukan tersebut adalah pertunjukan kesenian barong Using atau disebut juga barong Kemiren. Tentang seni pertunjukan Barong Using, Wahyuningsih (2014) menjelaskan, sebagai seni pertunjukan barong yang berada di Desa Kemiren, Kecamatan Glagah,
Kabupaten Banyuwangi yang masyarakatnya adalah orang Using yang masih menjaga nilai-nilai budaya Using lewat seni pertunjukan barong. Dalam pertunjukan kesenian barong Kemiren, terdapat unsure-unsur sejarah, seni tari, seni musik, dan berbagai jenis adegan yang dipadu dengan estetis dan dinamis. Sulistyani (2014) menjelaskan bahwa dalam konteks seni pertunjukan, barong Kemiren menjadi sebuah pertunjukan rakyat yang sederhana dan juga bisa difungsikan sebagai 
penyemarak iring-iringan pengantin atau arak-arakan, dramatari, maupun yang lainya.

Soedarsono (2010: 18) menjelaskan, Barong sebagai manifestasi kebaikan dan pelindung masyarakat. Kesenian barong Kemiren memiliki asal-usul yang awalnya diciptakan guna mengusir wabah penyakit Pagebluk. Kesenian barong Kemiren memiliki sejarah asal-usulnya yang diwariskan secara turun temurun. Pewarisan barong Kemiren dilakukan secara tradisi lisan, diwariskan kepada anak laki-laki yang disebut masih keluarga barong, dalam silsilah pewarisan barong dalam 7 generasi. Rahayu dan Hariyanto (2008: 28) menjelaskan, selain barong Kemiren, di Banyuwangi hingga saat ini hidup berbagai jenis kesenian barong dan masih fungsional dalam masyarakatnya seperti Barong Dhadhak Merak dalam pertunjukan kesenian Reog Ponorogo, Barong Prejeng, Barong Kumbo, Barong Sumur, Barong Bali yang biasanya terdapat dalam pertunjukan kesenian jaranan, Barong Cina, dan Barong Banyuwangi yang disebut dengan Barong Using. Wujud atau bentuk Barong Using memiliki ciri khas tersendiri bila dibandingkan dengan bentuk barong lain yang ada di Banyuwangi.

Hampir secara serempak Sutedjo, Budiardjo, \& Yurisma (2018) dan Rahayu dan Hariyanto (2008: 28) menjelaskan, berbagai jenis barong yang ada di Banyuwangi mulanya merupakan seni pertunjukan yang bersifat sakral, disajikan dalam berbagai ritual, dan pertunjukan barong menjadi bagian dari ritual. Akan tetapi, lambat laun nilai-nilai kesakralan tersebut semakin menipis, sejalan dengan perkembangan peradaban masyarakat
Banyuwangi yang menuju modern, sehingga kebutuhan akan ritual dan pertunjukan yang bersifat sakral dirasakan menjadi suatu kebutuhan yang bersifat sekuler. Pertunjukan barong yang semula bersifat sakral berubah menjadi pertunjukan yang bersifat profan tidak terkecuali bagi barong Using. Dewi (2015) menjelaskan, fungsi sakral barong digunakan sebagai selamatan ider bumi dan menjadi media utama dalam ritual ider bumi yang diadakan pada setiap tanggal 2 Syawal dalam kalender Hijriyah dan juga ritual selamatan desa besar yang diadakan selama 2 hari pada bulan Dzulhijah. Kini pelaksanaan ritual ider bumi dan selamatan desa diikuti dan dikemas menjadi obyek pariwisata budaya yang masuk dalam kalender pariwisata daerah. Barong dan sejumlah perangkatnya diarak keliling kampung sebagai wujud syukur masyarakat desa atas berkah yang melimpah pada kehidupannya selama setahun (Syaiful, Bayu, Purwandi, dkk, 2015: 51).

Secara profan, seni pertunjukan barong Kemiren difungsikan sebagai sarana hiburan pada acara hajatan dan sebagai seni pertunjukan pariwisata daerah (Rahayu dan Hariyanto, 2008: 32-33). Seni pertunjukan barong tidak mengalami perubahan dari rupa, bentuk, warna dan cerita sejak dahulu. Sebagai seni pertunjukan hiburan, masyarakat pendukung seni pertunjukan tersebut hanya sebatas masyarakat lokal antar desa yang masih menggemari seni pertunjukan barong. Lukman \& Huda (2017) menjelaskan, seni pertunjukan barong tidak hanya menjadi sebuah seni pertunjukan hiburan, kini seni pertunjukan barong dapat dinikmati oleh wisatawan dengan adanya festival budaya yang selalu dilaksanakan 
setiap tahun. Untuk pelaksanaan selamatan desa besar, guna dapat menarik kedatangan wisatawan berkunjung ke desa wisata, pemerintah daerah mengikutinya dengan serangkaian acara festival tumpeng sewu yang merupakan festival kuliner di desa Kemiren.

Perubahan fungsi dari sebuah seni pertunjukan yang bersifat sakral menjadi profan didukung oleh adanya pariwisata internasional yang memanfaatkan sebuah seni pertunjukan menjadi daya tarik bagi wisatawan. Pada negara-negara berkembang, fungsi seni pertunjukan sebagai presentasi estetis (aesthetic presentation) yang tumbuh subur sebagai seni pertunjukan yang disajikan kepada wisatawan, terutama wisatawan mancanegara. Terjadi perubahan kreasi dalam suatu seni pertunjukan wisata sebagai art by metamorphosis yang telah mengalami perubahan yang sangat berbeda dari seni yang diciptakan untuk kepentingan masyarakat setempat yang disebut sebagai art by destination (Soedarsono, 2010: 271).

Kehadiran negara dalam bidang seni pertunjukan, khususnya di Banyuwangi yang direpresentasikan oleh pemerintah Kabupaten Banyuwangi tampak pada berbagai kebijakan bidang kebudayaan. Khusus dalam bidang seni pertunjukan, hal tersebut berkaitan dan menjadi bagian dari pengembangan pariwisata di Banyuwangi. Kebijakan tersebut diawali Keputusan Bupati Banyuwangi Nomor 401 Tahun 1996 tentang penetapan Desa Kemiren sebagai lokasi desa wisata Using di Kabupaten Daerah Tingkat II Banyuwangi, oleh Bupati T. Purnomo Sidik pada 11 Juli 1996 (Anoegrajekti, 2018: 196).
Terdapat beberapa kelompok seni pertunjukan di desa Kemiren, seperti gandrung, barong, kuntulan, dan mocoan. Semuanya masih dihidupi, diminati, dan dikembangkan oleh masyarakat pendukungnya. Selain itu Desa Kemiren juga memiliki berbagai ritual seperti barong ider bumi, tumpeng sewu, dan mepe kasur (menjemur kasur) (Mudjijono dan Ariani, 2007: 19). Semua itu menjadi semakin bermakna untuk mendukung keberadaan Kemiren sebagai desa wisata Using yang terbagi menjadi beberapa anjungan, yaitu (1) Anjungan/Taman Rekreasi Desa Using, (2) Sanggar Genjah Arum, (3) Sanggar Barong Tresno Budoyo, (4) Sanggar Barong Lancing Sapu Jagad dan (5) Sanggar Barong Cilik Siswo Budoyo (Murdyastuti, dkk., 2016: 384).

Bagi industri pariwisata daerah, barong Kemiren menjadi sebuah pertunjukan yang dikemas dalam event pariwisata. Maka dari itu, di samping masyarakat Kemiren harus menjalankan adatnya yakni Idher Bumi dan Selamatan Desa, pemerintah daerah Banyuwangi mengemas dan mempromosikan kesenian tersebut menjadi kalender event pariwisata daerah. Dampak dari adanya industri pariwisata tersebut membawa perubahan secara sosial ekonomi dan sosial budaya. Secara sosial ekonomi akan menambah pemasukan daerah lewat wisatawan yang datang (Setianto, 2016:26); secara sosial budaya, adanya kepentingan dalam mengoptimalisasikan seni pertunjukan tersebut bagi sektor pariwisata sedikit merubah ketentuan adat ritual Ider Bumi dan selamatan desa yang dijalankan. Kajian ini difokuskan pada pembahasan mengenai (1) 
sejarah seni pertunjukan Barong Kemiren yang di dalamnya mengkaji prosesi ritual dengan terdapatnya nilai-nilai aspek sosial budayanya; dan (2) upaya optimalisasi seni pertunjukan barong kemiren masyarakat Using tahun 1996-2018 sebagai pemanfaatan pariwisata daerah kabupaten Banyuwangi.

\section{Barong dan Makna Filosofisnya}

Seni pertunjukan barong merupakan seni pertunjukan asli masyarakat Osing Banyuwangi. Seni pertunjukan ini lahir dan berkembang di desa Kemiren, Kecamatan Glagah, Kabupaten Banyuwangi. Lahirnya seni pertunjukan barong menjadi cikal bakal berdirinya desa Kemiren. Seni pertunjukan barong merupakan seni pertunjukan yang menggunakan media atau alat berupa seperangkat barong hasil cipta dan karya masyarakat Kemiren (Rahayu dan Hariyanto, 2008:10), sehingga seni pertunjukan barong tersebut berbeda dari seni pertunjukan barong lainnya. Kesenian barong Kemiren juga disebut dengan barong Using. Kini barong Using telah menyebar hingga seluruh wilayah Banyuwangi. Seni pertunjukan barong Kemiren awalnya memiliki fungsi sebagai kepentingan sacral, yang digunakan dalam prosesi ritual bersih desa Kemiren (Rahayu dan Hariyanto, 2008: 18).

Selama setahun, terdapat 2 kali proses ritual adat yang dijalankan yakni ritual adat Ider Bumi yang diselenggarakan setiap tanggal 2 Syawal dan ritual adat selamatan desa yang diselenggarakan setiap bulan Dzulhijah. Kesenian barong diwariskan secara turun temurun kepada keluarga barong sebagai pemangku adat kesenian tersebut. Tercatat telah 7 generasi yang mewarisi seni pertunjukan barong. Silsilah keluarga Uleg-uleg (Sur), Krepek (Sanimah), Canggah (Tompo), Buyut (Samsuri/Suroto), Kakek (Sapi'i), Bapak (Saleh), Сиси (Setyo Her Fendi), dengan ketentuan pewarisan barong yang dilakukan dengan syarat tidak boleh merubah bentuk, wujud, dan cerita dalam kesenian tersebut. Para pewaris barong menyampaikan asal usul kesenian barong yang diwariskan secara turun-temurun. Holt (1997: 67) menjelaskan, sebagai tradisi lisan yang diwariskan secara turun-temurun ditaati oleh seluruh masyarakat dan menjadi keterikatan adat dalam masyarakat. Barong digunakan untuk kepentingan ritual bersih desa guna tujuan menghindari bencana, yang dilakukan oleh seluruh masyarakat desa Kemiren sebagai keterikatan norma adat yang berlaku. Pewarisan barong dilakukan oleh silsilah keluarga barong dan ditaati oleh seluruh masyarakat Kemiren.

Barong diciptakan atas permintaan dhanyang Buyut Cili melalui mimpi. Dahulu desa Kemiren diserang wabah penyakit Pagebluk (Rahayu dan Hariyanto, 2008: 19). Uleg-uleg Sur mendapatkan mimpi bahwa untuk mengusir wabah penyakit pagebluk harus melakukan bersih desa dengan barong. Melalui mimpinya tersebut, uleg-uleg Sur membuat 2 buah barong yakni barong Sunar Udara dan barong Macan Lundoyo. Setelah melaksanakan ritual bersih desa tersebut, wabah penyakit pagebluk hilang dan ritual bersih desa tersebut terus dilakukan setiap tahunnya setiap tanggal 2 Syawal yang disebut Ider Bumi dan pada bulan Dzulhijah yang disebut selamatan desa hingga saat ini. Saat silsilah Buyut Samsuri usia remaja, 
barong telah berusia 250 tahun. Saat ini pun diperkirakan usianya lebih dari 450 tahun.

$$
\text { Lukman \& Huda (2017) }
$$

menjelaskan, barong digunakan sebagai media ritual ungkapan rasa syukur masyarakat Kemiren setiap tahunnya atas berkah yang diterima desanya. Selain berfungsi sakral, kesenian barong berfungsi secara profan sebagai seni pertunjukan hiburan yang terdiri dari 5 babak cerita pementasan, yakni babak pertama sunar Udara dan Jakripah, babak kedua Panji Sumirah, babak ketiga Jim Parahyangan, babak keempat, bayine Suwarti, babak kelima Macan Lundoyo (Wahyuningsih, 2014). Sebagai fungsi ritual, Ider Bumi tidak dapat dijalankan sendiri oleh keluarga barong. Ketua adat sebagai penganyom tradisi ritual Ider Bumi menjadi penghubung antar mayarakat yang menjalani dan mentaati norma adat dalam melaksanakan ritual Ider Bumi dan selamatan desa. Tidak hanya sebagai kepentingan ritual, kesenian barong mengandung nilai-nilai filosofis yang dijalankan dan ditaati masyarakatnya yang menjadikan sebagai pedoman kehidupan mereka. Holt (1997: 69) menjelaskan, nilai-nilai dalam tradisi masyarakat diwariskan secara turun-temurun dan menjadi bagian dari tradisi lisan, serta ditaati oleh seluruh masyarakat sebagai pendukung dalam pelaksanaan ritual.

Pewaris barong memiliki tanggung jawab besar dalam menjaga nilai-nilai tersebut untuk tidak mengalami perubahan dalam masyarakat. Karena kesenian barong diwariskan secara tradisi lisan sehingga riskan akan perubahan penyampaian, sehingga untuk menjaga nilai-nilai tersebut dilakukan melalui pelaksanaan ritual Ider
Bumi yang masih dilaksanakan setiap tahun hingga saat ini (Rahayu dan Hariyanto, 2008:24), dapat ditaati dan dijalankan masyarakat sebagai bagian dalam norma kehidupan bermasyarakat. Berawal dari kebutuhan sakral tersebut menjadi norma dalam masyarakat hingga saat ini, sehingga setiap tahun tetap dijalankan ritual bersih desa sebanyak 2 kali pada Ider Bumi tanggal 2 Syawal dan juga selamatan desa pada bulan Dzulhijah. Masyarakat menjadi terikat dalam melaksanakan ritual dan takut sesuatu akan menimpa mereka apabila tidak menjalankan ritual, sehingga kesenian barong menjadi pedoman dalam kehidupan (Setianto, 2016: 17).

Berdasarkan hasil wawancara (2018), kesenian barong Kemiren memiliki makna-makna filosofis yang terkandung dalam bentuk dan warna.

1). Bentuk barong seperti harimau bersayap dianggap sebagai hewan paling sakti dalam kepercayaan masyarakat Kemiren.

2). Mahkota barong memiliki nilai bahwa manusia harus memiliki hati yang besar lapang dada.

3). Gerudho memiliki nilai bahwa manusia perlu waspada menengok ke belakang.

4). Sayap memiliki makna bahwa manusia harus bisa mengayomi dan melindungi sesama.

5). Tanduk memiliki makna seluruh kekuatan berasal dari Tuhan Yang Maha Esa.

6). Warna barong yang terdiri dari pancawarna, merah melambangkan 
keberanian, hitam melambangkan kelanggengan, hijau melambangkan kesejahteraan, kuning melambangkan kelahiran dan kematian, dan putih melambangkan kesucian. Bentuk dan warna dalam kesenian barong menjadi pedoman kehidupan masyarakat Kemiren yang menyampaikan makna-makna nilai filosofis dalam kehidupan bermasyarakat.

Keluarga barong sebagai pelaku seni dan ritual melaksanakan ritual tersebut setiap tahunya dengan berpedoman pada tradisi yang diwariskan secara turuntemurun sejak dahulu. Keluaga barong tidak berani merubah ketentuan dan pelaksanaan ritual bersih desa. Mereka menjadi penanggung jawab pelaksanaan ritual bersih desa bagi kepentingan seluruh masyarakat desa Kemiren, dan melalui pedoman yang diwariskan tersebut menjadi tanggung jawab adat bagi keluarga barong sebagai pelaksana adat. Mereka terikat oleh ketentuan adat yang dibuat sehingga mengupayakan yang terbaik dalam pelaksanaan ritual dengan berpedoman pada tradisi yang diwariskan (Holt, 1997: 71).

Ritual adat Ider Bumi dan selamatan desa dilakukan setiap tahun. Ider Bumi dilaksanakan setiap tanggal 2 Syawal dan selamatan desa dilaksanakan setiap bulan Dzulhijah. Pelaksanaan bersih desa dilakukan pada hari-hari besar \& hari raya umat Islam seperti Idul Fitri dan Idul Adha. Pelaksanaan ritual dilakukan dengan arakarakan barong mengelilingi desa sebagai tolak bencana. Arak-arakan barong dimulai dari waktu setelah sholat Ashar berkeliling desa dari rumah pewaris barong menuju ujung Barat desa, kembali lagi ke Timur ujung desa, dan kembali lagi ke barat menuju rumah pewaris barong dan diakhiri sebelum waktu magrib. Akan tetapi, pelaksanaan ritual Ider Bumi dengan selamatan desa sedikit berbeda dari segi barong yang digunakan dalam arak-arakan. Apabila Ider Bumi hanya mengarak barong Sunar Udara dan juga 2 pithik-pithikan dengan diiringi penabuh gamelan, sedangkan selamatan desa dilakukan dengan mengarak seluruh barong dan perangkat-perangkatnya.

Terdapat beberapa perbedaan dari kedua prosesi ritual tersebut, antara lain, apabila pelaksanaan ritual Ider Bumi fokus prosesnya hanya terdapat pada pelaksanaan arak-arakan dan sedikit upacara tambahan untuk meramaikan acara; pelaksanaan ritual selamatan desa berfokus pada selamatan desa tersebut sebagai sarana tolak bala dan ungkapan rasa syukur terhadap Tuhan Yang Maha Kuasa atas berkah yang diterima desa selama setahun dengan diiringi makan bersama tumpeng yang disediakan oleh masyarakat (Rahayu dan Hariyanto, 2008: 40).

Proses ritual dan keagamaan lebih banyak pada pelaksanaan selamatan desa karena arak-arakan barong pun dilakukan 2 kali dan selamatan desa dilakukan 2 kali setelah arak-arakan pada sore hari dan setelah waktu magrib sebelum acara selamatan desa yang dilakukan dengan doa'doa. Selamatan desa juga dilakukan dengan mocoan lontar yusuf dan pertunjukan barong semalam sebagai bagian dari pelaksanaan ritual.

3. Upaya Optimalisasi Seni

\section{Pertunjukan Barong}




\section{1. Art By Destination dan Art By Metamorphosis}

Kesenian barong Kemiren berawal dari kebutuhan sakral masyarakat desa Kemiren untuk digunakan sebagai ritual bersih desa Kemiren. Kebutuhan sakral tersebut dilakukan dan ditaati oleh seluruh masyarakat desa Kemiren sebagai bagian dari norma kemasyarakatan yang berkembang di tengah-tengah perubahan zaman. Meskipun kesenian barong tetap dilakukan sebagai kebutuhan sakral setiap tahun hingga saat ini, kesenian barong kini juga dilakukan sebagai kebutuhan profan di tengah-tengah kehidupan masyarakat modern. Secara profan, seni pertunjukan barong Kemiren difungsikan sebagai sarana hiburan pada acara hajatan dan sebagai seni pertunjukan pariwisata daerah (Rahayu dan Hariyanto, 2008: 32-33). Sebagai seni pertunjukan hiburan, masyarakat pendukung seni pertunjukan tersebut hanya sebatas masyarakat lokal antar desa yang masih menggemari seni pertunjukan barong (Setianto, 2016:19). Tidak hanya menjadi sebuah seni pertunjukan hiburan, kini seni pertunjukan barong dapat dinikmati oleh wisatawan dengan adanya festival budaya yang selalu dilaksanakan setiap tahun (Dewi, 2015). Untuk pelaksanaan selamatan desa besar, guna dapat menarik kedatangan wisatawan berkunjung ke desa wisata, pemerintah daerah melengkapinya dengan serangkaian acara festival tumpeng sewu yang merupakan festival kuliner di desa Kemiren. Festival ini dilaksanakan dengan mengumpulkan 1000 (seribu) tumpeng lengkap dengan gunungan nasi kuning dan putih, dari masyarakat dan pemerintah, untuk diarak keliling kota, didoakan dan disajikan untuk dinikmati ramai-ramai sebagai tanda rasa syukur warga atas rahmat dan barokah yang dilimpahkan oleh Allah Yang Maha Kuasa.

Perubahan fungsi dari sebuah seni pertunjukan yang bersifat sakral menjadi profan didukung oleh adanya event pariwisata internasional yang memanfaatkan sebuah seni pertunjukan menjadi daya tarik bagi wisatawan. Pada negara-negara berkembang, fungsi seni pertunjukan sebagai presentasi estetis (aesthetic presentation) yang tumbuh subur sebagai seni pertunjukan yang disajikan kepada wisatawan, terutama wisatawan mancanegara. Oleh karena itu, terjadi perubahan fungsi dan makna dalam suatu seni pertunjukan wisata sebagai art by metamorphosis, yang telah mengalami perubahan yang sangat berbeda dari seni yang diciptakan untuk kepentingan masyarakat setempat yang disebut sebagai art by destination (Soedarsono, 2010: 271).

\section{2. Pemerintah dan Masyarakat}

Perkembangan pariwisata, sejalan dengan dinamika masyarakat global, telah merambah berbagai terminologi seperti, sustainable tourism development, village tourism dan ecotourism, yang merupakan pendekatan pengembangan kepariwisataan yang berupaya untuk menjamin agar wisata dapat dilaksanakan di daerah tujuan wisata bukan hanya di perkotaan (Syaiful, Bayu, Purwadi, dan Marhaedi, 2015: 140). Salah satu pendekatan pengembangan wisata alternatif adalah desa wisata dan ekowisata untuk pembangunan pedesaan yang berkelanjutan dalam bidang pariwisata. Desa 
wisata adalah suatu bentuk integrasi antara atraksi, akomodasi dan fasilitas pendukung yang disajikan dalam suatu struktur kehidupan masyarakat yang menyatu dengan tata cara dan tradisi yang berlaku (Nuryanti, 1993: 46).

Kehadiran pemerintah dalam bidang seni pertunjukan, khususnya di Banyuwangi yang direpresentasikan oleh pemerintah Kabupaten Banyuwangi tampak pada berbagai kebijakan bidang kebudayaan. Khusus dalam bidang seni pertunjukan, hal tersebut berkaitan dan menjadi bagian dari pengembangan pariwisata di Banyuwangi. Kebijakan tersebut diawali Keputusan Bupati Banyuwangi Nomor 401 Tahun 1996 tentang penetapan (Desa Kemiren sebagai) lokasi desa wisata Using di Kabupaten Daerah Tingkat II Banyuwangi, oleh Bupati T. Purnomo Sidik pada 11 Juli 1996 (Anoegrajekti, 2018:196). Penetapan tersebut berdampak pada penetapan lokasi pembangunan Desa Wisata Using di Kabupaten Daerah Tingkat II Banyuwangi, yang terletak di Desa Kemiren, sehingga berdampak pada perkembangan kelompok seni pertunjukan yang ada di Kemiren, yang merupakan salah satu konsentrasi hunian masyarakat Using.

Peran dan perhatian pemerintah daerah dan desa dalam mengembangkan pariwisata sangat baik, misalnya dengan melakukan promosi ritual melalui sosial media dan juga menjadikan ritual bersih desa sebagai acara festival budaya setiap tahunnya (Setianto, 2017: 20). Akan tetapi tampaknya perhatian pemerintah terhadap pelaksana ritual belum ada. Meskipun sebelum pelaksanaan terdapat musyawarah tetapi hirauan terhadap pelaksana ritual tidak ada dari desa. Oleh sebab itu, untuk melengkapinya, ritual Ider Bumi diselnggarakan ramai baru sekitar 6-7 tahun belakangan, melalui peran pemerintah daerah dan desa, dengan mempromosikannya melalui festival budaya.

Pemerintah daerah dan desa sangat mendukung dalam hal sektor pariwisata, sehingga masyarakat diberdayakan melalui parwisata desa tersebut. Kini semenjak penyelenggaraan Ider Bumi dan selamatan desa melalui wadah festival setiap tahun, desa Kemiren menjadi lebih dikenal masyarakat luas dan makin banyak mendapat kunjungan wisatawan. Untuk itu pemerintah daerah dan desa tidak berhenti dalam melakukan promosi pariwisata melalui media sosial. Strategi promosi juga dilakukan dengan pemerintah desa menyampaikan kepada Camat dengan mengundang seluruh dinas pariwisata dan juga agen-agen travel dan hotel untuk bersama-sama mempromosikan acara ritual Ider Bumi dan selamatan desa agar selalu ramai dikunjungi wisatawan (Dinas Pariwisata, 2018).

$$
\text { Upaya-upaya masyarakat desa }
$$
Kemiren dalam mengembangkan daerahnya sebagai desa wisata budaya dilakukan oleh Kelompok Sadar Wisata (Pokdarwis), sebagai kelompok sadar wisata desa Kemiren yang mengkoordinir upaya masyarakat dalam mengembangkan pariwisata. Pokdarwis sebagai kelompok yang juga bertugas dalam menghimpun dan memberdayakan masyarakat untuk memanfaatkan sektor pariwisata yang kini berkembang di desa Kemiren. Masyarakat desa Kemiren hidup guyub rukun dalam hal Ider bumi dan selamatan desa, dengan 
bersama-sama, dengan bergotong royong, misalnya mendirikan penjor dan panggung hiburan untuk pelaksanaan ritual bersih desa.

Dahulu sebelum diangkat menjadi festival budaya, pelaksanaan bersih desa hanya dilakukan lingkup desa, sekarang masyarakat mengembangkanya dengan menjual tumpeng untuk wisatawan ikut melaksanakan ritual. Fasilitas-fasilitas dibenahi termasuk menyediakan homestay bagi wisatawan yang berkunjung jauh-jauh hari sebelum penyelenggaraan upacara. Masyarakat juga guyub rukun, gotong royong menciptakan kerajinan tangan berupa kalung sapi sebagai ciri khas desa Kemiren yang mayoritas masyarakatnya bekerja sebagai petani. Upaya-upaya dilakukan dengan guyub rukun dan gotong royong dalam berbagai kegiatan untuk mengembangkan desa wisata, misalnya juga dengan mendirikan himpunan-himpunan beberapa kelompok seni pertunjukan yang ikut serta dalam ritual bersih desa. Terdapat beberapa kelompok seni pertunjukan yang ada di desa Kemiren, seperti gandrung, barong, kuntulan, dan mocoan, yang semuanya masih dihidupi, diminati, dan dikembangkan oleh masyarakat pendukungnya. Selain itu, masyarakat Desa Kemiren juga memiliki berbagai ritual seperti barong ider bumi, tumpeng sewu, dan mepe kasur (Mudjijono dan Ariani, 2007: 19).

Sedangkan peran kelompok masyarakat pendukung berperan dalam melakukan promosi pariwisata budaya di desa Kemiren. Seluruh kelompok masyarakat berperan, ikut andil dalam ritual bersih desa sehingga mereka melakukanya dengan kesadaran diri hidup gotong royong dengan sesama untuk mensukseskan pelaksanaan ritual bersih desa. Antar kelompok masyarakat memiliki peran sehingga tidak dapat dipisahkan kepentingan dan kebutuhannya dalam sebuah sistem organisasi kemasyarakatan. Di sisi lain terdapat kelompok masyarakat pelaku seni yang juga berperan dalam mendukung pariwisata budaya desa Kemiren. Semua itu menjadi semakin bermakna untuk mendukung keberadaan Kemiren sebagai desa wisata Using yang terbagi dalam anjungan-anjungan, yaitu

Anjungan/Taman Rekreasi Desa Using, (2) Sanggar Genjah Arum, (3) Sanggar Barong Tresno Budoyo, (4) Sanggar Barong Lancing Sapu Jagad dan (5) Sanggar Barong Cilik Siswo Budoyo (Murdyastuti, dkk., 2016: 384).

\section{3. Sosial Ekonomi dan Sosial Budaya}

Bagi industri pariwisata daerah, barong Kemiren menjadi sebuah tradisi yang dikemas menjadi event pariwisata. Maka dari itu, di samping masyarakat Kemiren harus menjalankan adatnya yakni Idher Bumi dan Selamatan Desa, pemerintah daerah Banyuwangi mengemas dan mempromosikan kesenian budaya tersebut masuk dalam kalender event pariwisata daerah. Dampak dari adanya industri pariwisata tersebut terasa secara sosial ekonomi dan sosial budaya. Secara sosial ekonomi kegiatan ini akan menambah pemasukan daerah lewat wisatawan yang datang (Setianto, 2016: 26). Secara sosial budaya, adanya kepentingan dalam mengoptimalisasikan seni pertunjukan 
tersebut bagi sektor pariwisata sedikit merubah ketentuan adat ritual Ider Bumi dan selamatan desa yang dijalankan. Kedatangan pariwisata dalam memanfaatkan budaya memberikan dampak sescara sosial budaya bagi keluarga barong dan masyarakat desa Kemiren, kini eksistensi kelestarian dan tumbuh kembangnya seni pertunjukan barong menjadi komoditi dalam menggerakkan perekonomian daerah. Kebijakan kebudayaan yang diterapkan dalam menggerakkan pembangunan desa wisata budaya dinilai sebagai strategi yang cukup jitu dan berhasil. Identitas barong sebagai seni pertunjukan diangkat dalam kegiatan festival daerah dalam upaya mempromosikan seni pertunjukan tersebut. Bahkan barong diangkat menjadi tema festival lainnya di Banyuwangi, seperti festival Banyuwangi Ethno Carnival (BEC) dengan menampilkan tema barong untuk mempromosikan seni pertunjukan barong pada kalangan luas (Setianto, 2017: 24).

Mengangkat khasanah seni pertunjukan barong dan tradisi masyarakat desa wisata sebagai bahan baku promosi dapat membawa nama daerah Banyuwangi baik di tingkat nasional maupun internasional. Hal tersebut berdampak pada meningkatnya jumlah wisatawan yang datang saat event tradisi budaya ritual Ider Bumi dan Tumpeng Sewu yang merupakan tradisi selamatan desa dengan menggunakan media barong setiap tahunya semenjak tahun 2013. Seperti pada tahun 2015, pemerintah daerah melakukan promosi pariwisata dengan melakukan promosi seni pertunjukan barong lewat festival Barongan Nusantara yang diselenggarakan pada tanggal 6 September 2015 dengan tujuan mengembangan promosi seni pertunjukan barong di lain festival Idher Bumi dan selamatan desa Kemiren (Setianto, 2017: 29).

Penyelenggaraan seni pertunjukan barong sebagai event of tourism yang dikemas dalam rangkaian Banyuwangi Festival, sudah mengarah pada sasaran yang dituju yakni menggairahkan industri pariwisata dan memberikan efek domino bagi keuangan dan kegiatan ekonomi kreatif di Banyuwangi. Nilai transaksi yang muncul dalam event seni pertunjukan barong yang digelar, selalu mengalami kenaikan dari tahun ke tahun (Setianto, 2017: 18). Hal tersebut dikuatkan oleh terbitnya perda Kabupaten Banyuwangi Nomor 1 Tahun 2017 tentang desa wisata bab 2 pasal 3 yang berisi sebagai berikut.

1). Meningkatkan kesejahteraan masyarakat desa.

2). Meningkatkan kesadaran masyarakat dalam mengembangkan potensi alam dan mengkonservasi/melestarikan adat, budaya serta arsitektur yang ada secara turun temurun.

3). Meningkatkan kesadaran masyarakat dalam konservasi satwa dan tumbuhan khas serta lingkungan alam.

4). Mendorong masyarakat untuk menciptakan lingkungan yang bersih, rapi dan sehat.

5). Mempercepat penanaman sikap dan keterampilan yang sesuai dengan sapta pesona Pariwisata Indonesia.

6). Menumbuhkan kebanggaan akan adat, budaya dan desanya (Dinas Pariwisata, 2018).

Selain yang terkait dengan pelaksanaan event wisata itu, banyak sektor 
lain yang turut bergerak menggiringnya yang di antaranya sektor industri kecil dan usaha-usaha kerajinan, usaha kuliner, usaha jasa transportasi, jasa perjalanan wisata, hingga akomodasi di desa wisata. Pada tahun 2014, menjelang penyelenggaraan ritual Ider Bumi, sejak 3 pekan sebelumnya homestay di desa wisata mulai kebanjiran pesanan. Rata-rata pemesannya adalah wisatawan dari luar wilayah Banyuwangi yang ingin menyaksikan langsung event tradisi ritual Ider Bumi dan selamatan desa. Terjadi transaksi ekonomi sekitar 200-300 juta saat event pelaksanaan ritual Ider Bumi dan selamatan desa (Setianto, 2017: 19).

Mengenai ekonomi kreatif yang tercipta di masyarakat dijelaskan oleh narasumber, masyarakat menciptakan ekonomi kreatif dalam memanfaatkan potensi pariwisata yang sedang berlangsung sehingga menjadi daya tarik dan ciri khas bagi wisatawan yang datang, menjadi lebih menarik dari pada daerah-daerah wisata lainya. Penjelasan narasumber menyebutkan bahwa terdapat nilai positif masyarakat, dengan menjual oleh-oleh dan juga souvenir, tetapi kegiatan jualan ini tidak berlaku untuk keluarga barong, mereka tidak diperbolehkan mengambil keuntungan. Keluarga barong hanya bertugas dalam melaksanakan ritual. Ekonomi kreatif dilakukan sebagian masyarakat Kemiren meski ada pula masyarakat yang lebih memilih untuk berpartisipasi melaksanakan ritual dari pada mencari keuntungan.

Sebagai desa penunjang wisata budaya Using, desa Kemiren memiliki pengelolaan pariwisata, yang juga dikelola oleh masyarakat. Masyarakat yang mengelola desa wisata sadar akan potensi yang dapat mereka manfaatkan. Semakin dikenalnya desa Kemiren sebagai desa wisata memunculkan peluang di masyarakat dalam membuka jasa dan industri ekonomi kretaif. Salah satu bentuk adanya ekonomi kreatif di desa wisata budaya yakni adanya homestay bagi wisatawan yang dikelola warga setempat, yang merupakan rumah pribadi masyarakat yang disewakan kepada wisatawan (Sedarmayanti, 2014: 103).

Homestay di desa wisata tersebut tidak pernah sepi dari wisatawan. Umumnya, masyarakat sebagai penyedia jasa telah memiliki rumah kedua apabila terdapat wisatawan yang hendak menyewa. Hasil wawancara terhadap informan sebagai narasumber menjelaskan bahwa sedikitnya terdapat 53 homestay yang terdaftar pada Kelompok Sadar Wisata, yang dikelola masyarakat di desa Kemiren untuk disewakan kepada wisatawan yang datang. Penghuni selalu ramai setiap harinya, karena tidak hanya wisatawan saja yang datang, tetapi dari kalangan mahasiswa maupun pelajar yang melakukan penelitian dan kunjungan di desa Kemiren pun juga memanfaatkan homestay yang disewakan (Wawancara Pribadi, 18 Maret, 2018).

Sebagian rumah-rumah pribadi yang dimanfaatkan masyarakat menjadi homestay, memiliki arsitektur khas rumah adat suku Using, sehingga menampilkan ciri khas bangunan sebagai desa wisata yang menarik wisatawan untuk tinggal (Mudjijono dan Ariyani, 2007:44). Selain itu, homestay yang memiliki arsitektur khas rumah adat suku Using di dalamnya terdapat perabotanperabotan rumah tangga khas suku Using. Jasa penyewaan homestay mengalami peningkatan jumlah pengunjung saat acara 
event pariwisata di Banyuwangi, terutama saat adanya event wisata budaya ritual Ider Bumi yang merupakan ritual medium bersih desa dengan seni pertunjukan barong di Kemiren (Setianto, 2017: 33). Tarif setiap homestay berbeda-beda, akan tetapi memiliki kecenderungan tarif rata-rata antara Rp.100.000-Rp.150.000/malam dengan diikuti penawaran yang berbeda setiap harga. Potensi yang sangat menguntungkan bagi masyarakat desa Kemiren terutama saat adanya event budaya ritual Ider Bumi di desa Kemiren.

Pengembangan sektor pariwisata bukan hanya sekedar gaya semata, tetapi juga karena efektifitasnya dalam menggerakkan perekonomian masyarakat. Data menunjukkan, pada tahun 2015 Wisman yang berkunjung ke Kabupaten Banyuwangi sebanyak 46.214 dan Wisnus 1.926.179, tahun 2017 Wisman 69.167, dan Wisnus 4.062.629 (Dinas Pariwisata, 2018). Terbukti, dalam event festival Ider Bumi membawa perekonomian kabupaten Banyuwangi terus menggeliat. Adapun pendapatan per kapita masyarakat Kemiren melonjak 80 persen dari Rp 2,7 juta per tahun pada tahun 2010 menjadi 3,77 juta per tahun pada 2015. Sektor pariwisata dikembangkan karena terbukti sangat efektif dalam menggerakkan ekonomi yang juga mendongkrak keuangan dan pendapatan masyarakat desa wisata.

Indikator ekonomi di desa Kemiren menunjukkan kecenderungan membaik. Ratio atau indikator kesenjangan di desa wisata budaya sudah menurun menjadi 0,29 yang semakin mendekati 0 , semakin baik, dan sudah lebih baik dari rata-rata daerah maupun provinsi (Setianto, 2017: 26). Data menunjukan, pada tahun 2017 sebanyak 4,228 orang dan tahun 2018 sebanyak 8,473 orang yang berkunjung ke desa wisata Kemiren (Pokdarwis Desa Kemiren, 2018).

Optimalisasi akan seni pertunjukan barong dikemas dalam keterkaitan lima pilar penyangga pengembangan pariwisata dan industri kreatif, yakni negara, pelaku seni dan ritual, masyarakat pendukung, industri, dan pemuka agama. Pilar-pilar ini bisa memberikan masukan yang tepat sehingga memunculkan respons yang baik dari kalangan pengusaha, birokrat, praktisi budaya, dan pelaku seni tradisi dan ritual (Anoegrajekti, 2018: 196-197). Kini seni pertunjukan barong mengalami banyak perubahan mulai dari struktur pertunjukan dan selingan-selingan yang menyertai. Ketika ekonomi berbasis sumberdaya alam semakin menurun karena keterbatasan bahan, industri kreatif berbasis pengetahuan dan talenta kreatif menjadi alternatif pilihan. Ketika industri budaya bermodal raksasa dianggap kurang memeratakan keuntungan finansial bagi masyarakat, industri kreatif dipandang sebagai bentuk aktivitas yang mendorong pemerataan (Anoegrajekti, 2016: 52). Artinya, seni pertunjukan barong sebagai industri pariwisata menciptakan sistem mata pencaharian bagi masyarakat yang sadar akan potensi pariwisata budaya. Industri budaya memang digerakkan para pemodal/perusahaan besar yang mencari keuntungan melalui "sistem industri budaya" dengan memproduksi dan mendistribusi produk budaya secara nasional (atau bahkan internasional) yang di dalamnya terdapat keseluruhan organisasi yang terlibat dalam proses penyaringan aneka produk dan ide baru yang berasal dari 
personel kreatif yang berada dalam level subsistem. Konsep industri kreatif sebagai bentuk usaha yang dikembangkan individu, institusi, atau komunitas berbasis pengetahuan dan kreativitas mereka, khususnya dalam hal seni pertunjukan, yang memberdayakan dan menyejahterakan kehidupan mereka (Anoegrajekti, 2016: 87).

\section{Simpulan}

Pandangan masyarakat Using, seni pertunjukan barong merupakan bentuk kesenian yang memiliki makna filosofis dalam pertunjukannya. Makna filosofis mengenai Barong Kemiren sampai saat ini masih dipercaya dan dipegang teguh oleh masyarakat Using. Seni pertunjukan barong Kemiren awalnya memiliki tujuan sebagai kepentingan ritual yang bersifat sakral berupa sarana medium ritual bersih desa yang menggunakan barong sebagai medianya, lalu berubah menjadi sebuah pertunjukan hiburan yang bersifat profan namun tidak melupakan aspek-aspek adat yang dipegang. Sebagai seni pertunjukan hiburan, seni pertunjukan barong memiliki masyarakat pendukung yang menggemari seni pertunjukan tersebut yang merupakan masyarakat lokal. Kini seni pertunjukan tersebut dikemas menjadi sebuah seni pertunjukan yang dapat menjadi obyek wisata budaya using. Sebagai bagian dari optimalisasi, seni pertunjukan barong Kemiren saat ini terus diperkenalkan secara luas oleh pemerintah daerah Banyuwangi, lewat event festival tahunan Ider Bumi dan selamatan desa yang bertujuan mendatangkan wisatawan serta menggerakkan perekonomian industri kreatif masyarakat Banyuwangi lewat pariwisata.

Sejak tahun 2013, seni pertunjukan barong menjadi bagian dari festival budaya sebagai penunjang wisata budaya using di Banyuwangi dan dalam konteks tersebut terdapat pemanfaatan budaya untuk diekploitasi dalam kemasan event kalender daerah. Eksploitasi budaya tersebut mempengaruhi terjadinya perubahan perilaku dan proses ritual itu sendiri. Keberadaan seni pertunjukan barong mendapat tempat tersendiri di tengah masyarakat. Masyarakat dan pemerintah secara aktif terlibat dalam penyelenggaraan ritual tahunan ini. Antusiasme pemerintah dan masyarakat dalam pengembangan industri kreatif dan pariwisata juga cukup tinggi. Untuk mengolah kebiasaan adat menjadi kemanfaatan pariwisata, terdapat keterkaitan lima pilar penyangga pengembangan pariwisata dan industri kreatif, yakni (1) Negara atau ;pemerintah, (2) pelaku seni dan ritual, (3) masyarakat pendukung, (4) industri, dan (5) pemuka agama. Pilar-pilar ini bisa memberikan masukan yang tepat sehingga memunculkan respons yang baik dari kalangan pengusaha, birokrat, praktisi budaya, dan pelaku seni tradisi dan ritual yang dapat menjadikan seni pertunjukan barong sebagai konsumsi wisata budaya using bagi wisatawan.

Potensi pariwisata daerah Banyuwangi dapat dioptimalkan lewat seni pertunjukan barong. Sebagai bagian dalam mengoptimalisasi potensi budaya using tersebut, terdapat kreasi yang dilakukan dalam pelaksanaan ritual Ider Bumi dan selamatan desa. Kini semakin banyak tambahan acara yang disajikan dalam 
pelaksanaan ritual, yang menjadi bukti dari upaya optimalisasi wisata budaya untuk meramaikan acara ritual Ider Bumi guna menciptakan kondisi yang menyenangkan bagi wisatawan yang berkunjung. Optimalisasi seni pertunjukan barong menjadi obyek wisata budaya using yang menjanjikan perubahan bagi masyarakatnya mendapat dukungan dari pemerintah daerah serta kerjasama antara berbagai pihak di dalamnya seperti kepala desa, kelompok Pokdarwis desa Kemiren, kelompok Bumdes (Badan Usaha Milik Desa) Kemiren dalam mengupayakan optimalisasi seni pertunjukan barong sebagai wisata budaya using. Berbagai pihak turut andil dalam pelaksanaan optimalisasi tersebut untuk mengembangkan wisata budaya using, sehingga terjadi optimalisasi terhadap wisata budaya using di desa Kemiren. Diperlukan penelitian lebih lanjut terkait analisis mendalam tentang dampak sosial ekonomi dan sosial budaya dari adanya upaya optimalisasi seni pertunjukan barong desa Kemiren di masa yang akan datang, sehingga dapat memberikan penjelasan mendalam berupa analisis kuantitatif dan kualitatif tentang sektor-sektor sosial ekonomi dan sosial budaya penggerak optimalisasi.

\section{Daftar Pustaka}

Anoegrajekti, N. 2016. Kebudayaan Using: Konstruksi, Identitas Dan Pengembanganya. Yogyakarta: Penerbit Ombak.

Anoegrajekti, N. 2018. Potensi Budaya Using Dan Industri Kreatif. Yogyakarta: Penerbit Ombak.
Dinas Kebudayaan Dan Pariwisata Kabupaten Banyuwangi. 2018. Laporan Kunjungan Wisatawan Daerah Banyuwangi. Direktorat Kementrian Pariwisata Republik Indonesia.

Holt, C. 1997. Melacak Jejak Perkembangan Seni di Indonesia. Bandung: Art Line.

Mudjijono dan Ariani, C. 2007. Komunitas Adat Using Di Desa Kemiren, Kecamatan Glagah Kabupaten Banyuwangi. Departemen Kebudayaan Dan Pariwisata Direktorat Jenderal Nilai Budaya Seni Dan Film.

Murdyastuti, Anastasia; Suji; dan Hermanto Rohman. 2016. Strategi Kebijakan Pengembangan Kawasan Wisata Using: Studi di Desa Kemiren Kecamatan Glagah Kabupaten Banyuwangi, dalam Kebudayaan Using: Konstruksi, Identitas, dan Pengembangannya. Yogyakarta: Penerbit Ombak.

Nuryanti, W. 1993. Concept, Perspective and Challenges, Konferensi Internasional mengenai Pariwisata Budaya. Yogyakarta: Gadjah Mada University Press.

Pokdarwis. 2018. Laporan Tahunan Optimalisasi Potensi Desa Wisata Budaya Using. Kelompok Sadar Wisata Desa Kemiren, Kecamatan Glagah, Kabupaten Banyuwangi.

Rahayu, E.W. dan Hariyanto, T. 2008. Barong Using Aset Wisata Budaya Banyuwangi. Banyuwangi: Dinas 
Kebudayaan Dan Pariwisata Kabupaten

Banyuwangi

Sedarmayanti. 2014. Membangun \& Mengembangkan Kebudayaan \& Industri

Pariwisata. Bandung: Refika Aditama.

Setianto, E. B. 2016. Bunga Rampai Ritual Adat Dan Tradisi Masyarakat Banyuwangi. Banyuwangi: Dinas Kebudayaan Dan Pariwisata Banyuwang

Setianto, E. B. 2017. Analisis Kebijakan Bupati Dalam Pelestarian Seni Dan Budaya Untuk Menunjang Pariwisata Banyuwangi. Banyuwangi: Dinas Kebudayaan Dan Pariwisata Banyuwangi.

Soedarsono, R. M. 2010. Seni Pertunjukan Indonesia di Era Globalisasi. Yogyakarta: Gadjah Mada University Press.

Syaiful, M, Bayu, A, Purwandi, A dkk. 2015. Jagat Osing Seni, Tradisi dan Kearifan Lokal Using. Dirjen Kebudayaan: Kementerian Pendidikan dan Kebudayaan Republik Indonesia. 